\title{
Qualitative Research on the Viewpoints of Parents Regarding Active Games Played by the Children Aged Between 4-5
}

\author{
Hacer Ozge Baydar \\ Emre Ozan Tingaz \\ Muhsin Hazar \\ Gazi University, Sport Sciences Faculty, \\ Gazi Mahallesi Abant Sokak, Yenimahalle, Ankara, Turkey \\ Kurset Hazar \\ Muğla Sitkı Koçman University, School of Physical Education and Sport \\ Belgin Gokyurek \\ Gazi University, Sport Sciences Faculty, \\ Gazi Mahallesi Abant Sokak, Yenimahalle, Ankara, Turkey
}

doi: 10.19044/esj.2017.v13n5p99 URL:http://dx.doi.org/10.19044/esj.2017.v13n5p99

\begin{abstract}
The purpose of this study is to examine the viewpoints of parents on their 4-5-year-old children who were playing active games. The parents had expressed that active games have positive influences on the cognitive development of children. Also, it has a significant influence on the decisionmaking process and focusing in general. Majority of the parents stated that active games have positive influences on the emotional development of their children in general terms. They expressed this with the term "being happy" and "being able to express oneself". The parents, who thought that active games have negative influences on the emotional development of their children, expressed this as "being angry". On the other hand, the parents also thought that active games contribute greatly to the psychomotor development of their children. Thus, they expressed this as "positive influences on physical development of their children". As the last item, the parents considered active games to have positive contributions to the social development of their children. They, however, expressed this thought with expressions like "being social, establishing communications, learning sharing, etc.". In conclusion, it has been observed that the viewpoints of the parents on active games were generally positive in terms of cognitive, emotional, and social and psychomotor development areas.
\end{abstract}


Keywords: 4-5 ages, parents' views, qualitative research, active games, children.

\section{Introduction}

The main function of playing games on the part of the child is to facilitate the child's adaptation to the world around him/her. A child understands what the real world is all about by playing games. However, she/he copes with undesired conditions by playing games as well as building up the basic foundations of lingual and conceptual developments through games. She/he also tries various social roles through the games she/he plays. She/he explores the stimulators which they cannot always find in a ready form in the real world through the games. In short, a game is as beneficial for a child as it is for anyone else (Bacanl1, 2002).

Therefore, games are activities which are performed outside people's daily activities. They are played for certain purposes (e.g. entertainment, education, health). Additionally, they are also played by means of physical and mental skills and by obeying the rules specific to the game itself within a limited place and time. They constitute a group through voluntary participation and which results to the development of social adaptation and emotional maturity. Also, they are based on talent, intelligence, attention, skill, and coincidence that keep participants and mostly the audience under their influence. Consequently, they are also accompanied by a sense of tension which results to activities that do not gain materialistic advantage but often gives pleasure (Hazar, 2006). A child either plays games by himself or with other children or even with adults. As such, any type of game teaches her/him something else. Children increase their knowledge levels by speaking, by watching others, by compiling new scenarios, and by exchanging imaginations (Auerback, 2008).

Above all, a game is a requirement for children. It is a method through which the child meets her/his movement needs. Thus, a child comes under the influence of two elements while playing. The first element is the family and the natural and cultural environment she/he exists in, while the second is the characteristics such as intelligence, perception, interpretation, creation, and social reaction that she/he genetically carries. Although a child grows up and develops more slowly than other living species, she/he has to learn and develop quite a lot of things from other species. However, the leading element affecting a child's growth and development is the game (Hazar, 2006).

Playing games is one of the basic requirements for children in preschool period. To ensure the healthy development of children, they need games as much as they need nutrition, sleep, etc. 
If this basic requirement is not met or is restricted, this causes children, who constitute the nucleus of society, to develop in an unhealthy manner (Kandir, 2000).

Games and sometimes toys, that are used within the game or are complementary elements of the game, contribute to the mental development of the child through thinking and exploration processes as well as in developing the physical skills of the child. They assist the child in using the language and in establishing a communication. Thus, this makes it possible for her/him to socialize. Separately, children live and experience the emotions within the game they play (Özdoğan, 2000).

Physical activities stimulate growth and provide an improved physical and psychological health. Since performing a physical activity boosts health level, the children with good strength levels are observed to be mentally and even more fluent as well. Nevertheless, even a physical activity on a moderate level is seen to reinforce a child's abilities, such as arithmetics, reading, recalling, etc. Apart from participating in simple physical events, sports practices in particular provide the child with even more benefits than merely his/her health. Thus, much contribution is made to both the psychological and social developments of the child (Gül, 2011).

According to Huizinga (2013), the chance to play real games for children under today's conditions is on the decrease with each passing day. Thus, this is represented by the fact that children are caged in home life, nursery schools, and schools. In addition, they are also forced to become successful.

Games generally influence children in many respects and contribute to their development. Within the game, particularly within the games requiring struggle and effort, children are faced with running, jumping, climbing up and down, pulling, pushing, wrestling, and carrying things continually. In short, they need to struggle along with their bodily features. Game activities helps to strengthen and improve the bone structure and joint structures (Hazar, 2006). The basis of the movement system is composed of muscles in an active sense and of bones in a passive sense. However, movement help these bones to become stronger (Mirzeoğlu, 2011).

A game helps the child to acquire skills that are compatible with his/her development level. The gross motor skills of the children aged between 3-6, such as jumping, hopping, and leaping from somewhere as well as climbing, staying balanced and tumbling, is also developed as well (Aksoy et al., 2014).

Piaget's game theory is based on cognitive development. Piaget dealt with game in terms of its structure. A game, according to Piaget, is an important element that is found in human behaviour and that supports the cognitive development of a child. Piaget advocates the fact that there is a 
relationship between game development and cognitive development. Games are seen to be effective on improving problem-solving skills. A game provides a space for the problem solving process. Therefore, as the child is forced into doing something, she/he may generate solutions through physical and mental trials and errors. As the child's problem-solving skills improves, she/he establishes connections between objects, words, and ideas. In addition, she/he may generalize these to the situations that they have never been confronted with before (Aral, et al., 2001).

Children have to show respect towards others' rights and even accept defeat within a game, or else they will be disqualified from the game once again. Through this way, they learn how not to react against others, how to show respect towards others, and how to accept their status within the game. Thus, this is quite important in social life and it is, in this sense, learnt through games (Hazar, 2006).

Games are of great importance in terms of not only educational status but also in terms of psychological health. They also prepare the most appropriate conditions for starting emotional relations. Many emotional responses or reactions, such as happiness, joy, pain, sympathy, fear, anxiety, friendship, hostility, grudge, hatred, love, loving someone, being loved, trust, reliance, dependence, independence, and death, are all learnt by the child through games (Başaran, 1992).

While playing games, children acquire superiority concerning themselves and notice their own power in their relationships with others. They apprehend social values like roles and responsibilities. They establish better communiations and internalize the concepts like reasoning or making judgements (Auerback, 2008).

The fact that children play together the games that they themselves or their friends have chosen helps their social-emotional skills develop, particularly during childhood. Therefore, children not only play games, but they improve and learn for the sake of becoming sociable and happy individuals in the society as well (Aksoy et al., 2014).

\section{The Objective and Importance of this Study}

The objective of this study is to determine the viewpoints of parents on the active games played by their children aged 4-5. The concept of active games mentioned in this study comprises of active games played with materials (collective games, playing with toys, materials of children's playground, etc.) as well as active simple games (hide-and-seek, blind man's bluff, playing tag, etc.). This study is important in terms of performing an assessment by determining the viewpoints of parents on their children aged 4-5 who play active games and also in terms of bringing forward suggestions at this point. 


\section{Materials and methods}

In this study, the semi-structured interview, one of the qualitative research methods, was used. In this semi-structured interview, some parts of the interview have been structured, whereas some other parts have not been structured. Thus, the type of interview at issue consists of the questions that allows an individual to give an unconstrained reaction to the questions asked (Erkuş, 2005).

\section{Study Group}

In this study, the maximum variation sampling method, which is one of the purposeful sampling methods, was applied. The objective in this sampling is to diversify the participants incorporated into the partial small sampling that is formed as much as possible (Y1ldirım et al., 2013). In line with this, the group of participants comprises of parents with different demographic information, such as age, occupation, educational status, income level, and settlement type.

\section{Data Collecting Tool}

In this study, open-ended questions were developed by the researchers, and an interview form of 17 questions was prepared for the pilot study. This interview is one of the most common data collection methods used in a qualitative research. The reason for this is that this type of interview is powerful in terms of revealing the emotions, thoughts, and experiences of the participants by taking their speech as the basis (Y1ldirim et al., 2013).

These interview questions were reviewed by both in-field and offfield experts based on the result of which some corrections were made. Along with the ultimate interview form, a pilot study was conducted with 5 parents. Raising open-ended questions in the first place for the discovery or as the pilot stage as well as using these results within the structured question form were the suggestions of the karma-method approach (Bernard et al., 2015). As the result of the pilot study and the opinions of in-field and offfield experts, the interview form consisting of 17 questions was reduced down to 8 questions. These questions, however, were thought to be of service to this study. The ultimate form was determined as the interview form of this study. Within the personal information form contained in the interview form are the ages, educational status, occupations, monthly income levels, and settlement/residence types (e.g. apartment building, detached house, etc.) pertaining to the parents in question. The main questions included in the interview form, on the other hand, are as follows:

S1. Does your kid play active games?

S2. Where does your kid play active games at most outside the school? 
S3. Who does your kid play active games with?

S4. For how long does your kid play active games on a daily basis?

S5.What kind of active games does your kid play?

S6. How do you think active games would affect your child's cognitive development?

S6. How do you think active games would affect your child's emotional development?

S7. How do you think active games would affect your child's psycho-motor development?

S8. How do you think active games would affect your child's social development?

\section{Data Analysis}

The interviews were performed using the voice-record feature of the cell phone as well as by taking down some notes. Afterwards, these data were transformed into a written text on the computer environment. The data were analyzed according to the descriptive and content analysis method. Therefore, the main purpose in the content analysis in which the data are analyzed in further depth is to create themes by conceptualizing the collected data and by interpreting them in a way that the reader can understand.

The data summarized and interpreted in the descriptive analysis are subjected to a more in-depth process in the content analysis. Thus, the concepts and themes that cannot be noticed through the descriptive approach can be discovered as the result of this analysis (Y1ldirım et al., 2013). In line with this, the questions within the interview form were encoded and separated into themes. Also, their frequency values in accordance with the frequency of repetitions were given and turned into a table. Prior to the stage of asking the questions in the interview form to the parents, the concept of active games was explained to them in detail.

\section{Validity and Reliability of the Research}

In qualitative researches, it is important that the data should be presented in a clear and detailed manner as much as possible for the validity and reliability of the research results (Yıldırım et al., 2013). In line with this, the views of the participants in this study were presented clearly and in detail. In addition, variation (diversification) and participant confirmation methods were applied as well. In order to be able to learn different aspects and formations of reality, the researcher has to find out different viewpoints, different meanings, different indicators and resources relative to the event, and the case she/he researches into. However, it is natural that there be different perceptions, experiences, and point of views pertaining to the data resources (that is, the individuals) that exist within the environment where 
the research is focused on. Rather than reaching a common result by filing these differences, the researcher should exhibit these differences with all their richness as much as she/he can. Otherwise, the effort to reveal and generalize the reality of the majority may pose a major threat to the validity of the research. To this end, the researcher is expected to apply the variation (diversification) strategy as well as increase the credibility of the research and its results. A research in which there is no variation (diversification) on any dimension may remain weak in terms of validity and reliability (Yıldırım et al., 2013). The participant confirmation is the verification of the data obtained in the research as well as the verification of the results and the interpretations attained by the researcher with respect to them. Therefore, these were provided by the data resources (participants). The data obtained from the interview were provided in their raw form within the study and were also subjected to an expert's review. During the expert's review, the involved expert reviews the processes taking place from the research design up to the collected data, up to their analysis and to the editing of the results through a critical eye, and then the expert gives feedback to the researcher (Y1ldirım et al., 2013).

For the reliability calculation of the research, the reliability formula (Reliability= Consensus/ (Consensus + Dissensus)) proposed by Miles and Huberman (1994) was used. As the result of the calculations, the reliability of the research was determined to be $92 \%$. The escalation of the reliability calculations towards over $70 \%$ is accepted to be reliable for the research (Miles et al., 1994).

\section{Findings}

1.Demographic Data pertaining to Parents and Their Children

Table 1. Demographic Data of Parents

\begin{tabular}{|c|c|}
\hline AGE RANGE & $26-47$ \\
\hline MOTHER & 12 \\
\hline FATHER & 6 \\
\hline TOTAL & 18 \\
\hline
\end{tabular}

When Table 1 is reviewed, the participant group of the study consists of 18 parents: 12 of whom are mothers and 6 of whom are fathers. The age range of the parents is 26-47.

Table 2. Demographic Data of Children

\begin{tabular}{|c|c|}
\hline Female & 9 \\
\hline Male & 9 \\
\hline TOTAL & 18 \\
\hline
\end{tabular}


When Table 2 is reviewed, it was seen that a total of 18 children were aged 4-5: 9 of whom were female and 9 of whom were male participated in the study.

Table 3. Educational Status of Parents

\begin{tabular}{|c|c|c|}
\hline \multirow{7}{*}{ 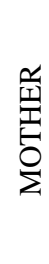 } & Primary School & 2 \\
\hline & Secondary School & - \\
\hline & High School & 4 \\
\hline & Associate Degree & 3 \\
\hline & Bachelor's Degree & 5 \\
\hline & Post-graduate & 3 \\
\hline & Doctorate & 1 \\
\hline \multirow{7}{*}{ 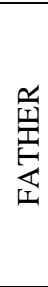 } & Primary School & 1 \\
\hline & Secondary School & - \\
\hline & High School & 3 \\
\hline & Associate Degree & 2 \\
\hline & Bachelor's Degree & 5 \\
\hline & Post-graduate & 6 \\
\hline & Doctorate & 1 \\
\hline
\end{tabular}

When Table 3 was reviewed, it was seen that the number of mothers who are primary school graduates was 2 . There are no mother who is a secondary school graduate, and the number of mothers who are high school graduates was 4 . The number of mothers who have associate's degree was 3 , the number of mothers who have bachelor's degree was 5 , the number of mothers who have post graduate degree was 3 , and the number of mothers who have doctor's degree was 1 . When the educational status of the fathers was reviewed, it was seen that the number of fathers who are primary school graduates was 1 . There is no father who is a secondary school graduate. The number of fathers who are high school graduates was 3, the number of fathers who have associate's degree was 2 , the number of fathers who have bachelor's degree was 5 , the number of fathers who have post graduate degree was 6 , and the number of fathers who have doctor's degree was 1 .

Table 4. Occupational Status of Parents

\begin{tabular}{|c|c|c|}
\hline \multirow{7}{*}{ 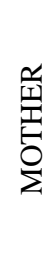 } & Housewife & 9 \\
\hline & Teacher & 3 \\
\hline & Doctor & 2 \\
\hline & Pharmacist & 1 \\
\hline & Civil Servant & 1 \\
\hline & Engineer & 1 \\
\hline & Biologist & 1 \\
\hline \multirow{6}{*}{ 舀 } & Civil Servant & 5 \\
\hline & Self-Employed & 5 \\
\hline & Engineer & 4 \\
\hline & Doctor & 2 \\
\hline & Lawyer & 1 \\
\hline & Teacher & 1 \\
\hline
\end{tabular}


When Table 4 was reviewed, it was seen that the occupational statuses of the mothers are as follows: 9 of them are housewives, 3 of them are teachers, 2 of them are doctors, whereas 1 of them is a pharmacist, 1 of them is a civil servant, 1 of them is an engineer, and 1 of them is a biologist. When the occupational statuses of the fathers are reviewed, on the other hand, it is seen that 5 of them are civil servants, 5 of them are self-employed, 4 of them are engineers, whereas 2 of them are doctors, 1 of them is a lawyer, and 1 of them is a teacher.

Table 5. Monthly Income Levels of Parents

\begin{tabular}{|c|c|}
\hline Amount of Income & $\begin{array}{c}\text { Number of } \\
\text { Parents }\end{array}$ \\
\hline $2000-5000$ TRY & 9 \\
\hline $5000-8000$ TRY & 6 \\
\hline $8000-11000$ TRY & 3 \\
\hline
\end{tabular}

When Table 5 was reviewed, it was seen that there are 9 families with the amount of income ranging between 2000-5000 TRY, while there are 6 families with the amount of income ranging between 5000-8000 TRY. In addition, there are 3 families with the amount of income ranging between 8000-11000 TRY.

Table 6. Neighbourhood of Residence and Settlement Type

\begin{tabular}{|c|c|}
\hline Keçiören & 8 \\
\hline Yenimahalle & 4 \\
\hline Çankaya & 3 \\
\hline Etimesgut & 2 \\
\hline Mamak & 1 \\
\hline Detached House & 2 \\
\hline Apartment Building & 16 \\
\hline
\end{tabular}

When Table 6 was reviewed, it was seen that the number of families residing in Keçiören was 8, the number of families residing in Yenimahalle was 4 , the number of families residing in Çankaya was 3 , the number of families residing in Etimesgut was 2, and the number of families residing in Mamak was 1 . Also, there are 2 families living in detached houses, whereas 16 families are known to be living in an apartment building.

2. Findings pertaining to the viewpoints of parents about the Active Games played by their Children aged 4-5

Table 7. Does your kid play active games?

\begin{tabular}{|c|c|}
\hline Yes & 18 \\
\hline No & - \\
\hline
\end{tabular}

In Table 7, it was determined that the children of all the parents who participated in the study had played active games. 
Table 8. Where does your kid play active games at most outside the school?

\begin{tabular}{|c|c|c|c|}
\hline Category & Sub-Category & Codes & $\mathrm{f}$ \\
\hline \multirow{6}{*}{ 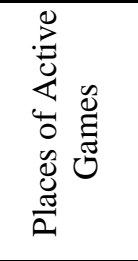 } & Closed Area & Home & 9 \\
\hline & \multicolumn{2}{|c|}{ Total } & 9 \\
\hline & \multirow{3}{*}{ Open Area } & Park & 5 \\
\hline & & Garden & 3 \\
\hline & & Street & 1 \\
\hline & \multicolumn{2}{|c|}{ Total } & 9 \\
\hline & \multicolumn{2}{|c|}{ Final Total } & 18 \\
\hline
\end{tabular}

\begin{tabular}{|c|c|c|c|}
\hline Category & Sub-Category & Codes & $\mathrm{f}$ \\
\hline \multirow{6}{*}{ 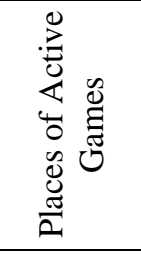 } & Closed Area & Home & 9 \\
\hline & \multicolumn{2}{|r|}{ Total } & 9 \\
\hline & \multirow{3}{*}{ Open Area } & Park & 5 \\
\hline & & Garden & 3 \\
\hline & & Street & 1 \\
\hline & \multicolumn{2}{|r|}{ Total } & 9 \\
\hline & \multicolumn{2}{|r|}{ Final Total } & 18 \\
\hline
\end{tabular}

In Table 8, in line with the answers given by the participants to the question, "Where does your kid play active games at most outside the school?", the sub-categories known as "Closed Area" and "Open Area" showed up. Thus, it is seen that the participants expressed only "Home" in the sub-category called "Closed Area", whereas they expressed the codes, "Park (9), Garden (5), and Street (1)", in the sub-category called "Open Area”.

Table 9. Who does your kid play active games with?

\begin{tabular}{|c|c|}
\hline Parents & 8 \\
\hline Friends & 7 \\
\hline By himself & 3 \\
\hline Siblings & 2 \\
\hline Relatives & 2 \\
\hline
\end{tabular}

When Table 9 was reviewed, the participants' children were seen to play together with their parents at most (8), with their friends (7), by themselves (3), with their siblings (2), and with their relatives (2).

Table 9. For how long does your kid play active games on a daily basis?

\begin{tabular}{l|l}
18 children & $1-3$ hours \\
\hline
\end{tabular}

In Table 9, in line with the information provided by the participants, it was seen that their children play active games for 1-3 hours a day. 
Table 10. What kind of active games does your kid play?

\begin{tabular}{|c|c|c|c|}
\hline 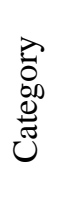 & 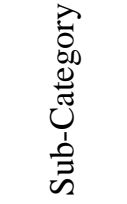 & Codes & $\mathrm{f}$ \\
\hline \multirow{13}{*}{ 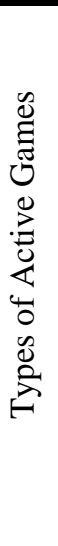 } & \multirow{4}{*}{ 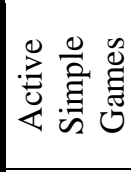 } & Hide-and-Seek & 9 \\
\hline & & Playing tag & 9 \\
\hline & & Blind man’s Bluff & 3 \\
\hline & & Total & 21 \\
\hline & \multirow{9}{*}{ 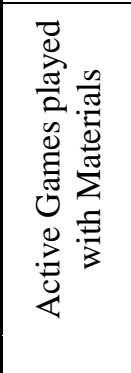 } & Playing with Toys & 10 \\
\hline & & Collective Games & 5 \\
\hline & & $\begin{array}{l}\text { Lego-jenga } \\
\end{array}$ & 5 \\
\hline & & Playing with the Materials of Children's Playground & 4 \\
\hline & & Coloration Games & 3 \\
\hline & & Jigsaw Puzzle-Model Games & 3 \\
\hline & & Playing with Play Doughs & 1 \\
\hline & & Total & 31 \\
\hline & & Final Total & 52 \\
\hline
\end{tabular}

When Table 10 was reviewed, the sub-category known as "Active Simple Games”, which belongs to the category “Types of Active Games”, was composed of the games: Hide-and-Seek (9), Playing tag (9), and Blind man's Bluff (3). Thus, the frequency value in total is 21 . The second subcategory called “Active Games played with Materials”, on the other hand, comprises of Playing with Toys (10), Collective Games (5), lego-jenga (5), Playing with the Materials of Children's Playground (4), Coloration Games(3), Jigsaw Puzzle-Model Games (3), and Playing with Play Doughs (1). Thus, the frequency value proved to be 31 in total.

Considering the participants' statements over the sub-category, "Active Simple Games";

Participant 1. "Playing tag, Hide-and-Seek, Lego, Cards, Jigsaw Puzzles...", Bluff...,"

Participant 2. “Hide-and-Seek, Playing tag, Blind man's

Considering the participants' statements over the sub-category, "Active Games played with Materials"; cars...."

Participant1. "Cars, Bowling, Coloration, Making model

Participant 2. "Lego, Barbie dolls, and various educational and instructive toys, Jigsaw Puzzles, Coloration...”’ 
Table 11. How do you think active games would affect your child's cognitive development?

\begin{tabular}{|c|c|c|c|}
\hline $\begin{array}{l}\text { Main } \\
\text { Category }\end{array}$ & Sub-Category & Codes & $\mathrm{f}$ \\
\hline \multirow{10}{*}{ 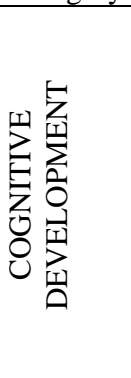 } & \multirow{10}{*}{ 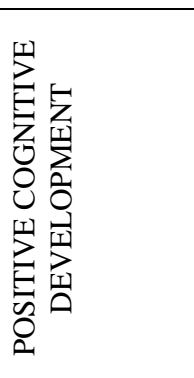 } & Making a Decision & 9 \\
\hline & & Focusing & 5 \\
\hline & & Thinking & 3 \\
\hline & & Adaptation & 2 \\
\hline & & Learning by Doing and Living & 2 \\
\hline & & Memory & 1 \\
\hline & & Perception & 1 \\
\hline & & Organizing (organization) & 1 \\
\hline & & Exploring Differences & 1 \\
\hline & & TOTAL & 25 \\
\hline
\end{tabular}

When Table 11 was reviewed, it was seen that the main category referred to as "Cognitive Development" has only one sub-category called "Positive Cognitive Development". However, the codes are as follows: Making a Decision (9), Focusing (5), Thinking (3), Adaptation (2), Learning by Doing and Living (2), Memory (1), Perception (1), Organizing (organization) (1), Exploring Differences (1), which, in total has the frequency value (25). Considering the participants' statements;

Participant 1: "I guess these games influence them in a positive way...I think they influence the children in a positive way intellectually in terms of making decisions".

Participant 2: "He has improved better, and his perspective towards relationships is even better".

Participant 3: "He would sometimes fail to defend himself when he played with dominant children, but now that has changed in time. His feeling of jealousy diminished. His ability to express himself improved”.

Table 12. How do you think active games would affect your child's emotional development?

\begin{tabular}{|c|c|c|c|}
\hline Category & Sub-Category & Codes & $\mathrm{f}$ \\
\hline \multirow{16}{*}{ 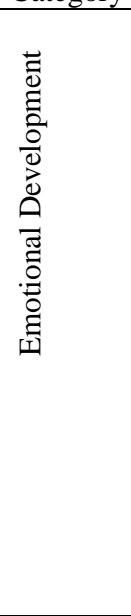 } & \multirow{4}{*}{ 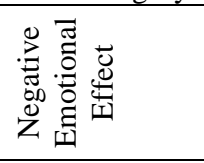 } & Being rageful & 3 \\
\hline & & Being stubborn & 2 \\
\hline & & Being sad & 2 \\
\hline & & Total & 7 \\
\hline & \multirow{13}{*}{ 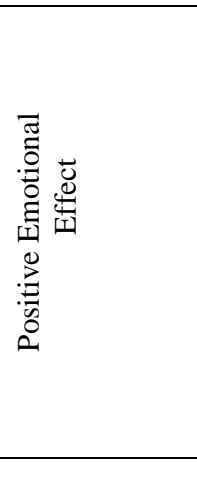 } & Being Happy & 7 \\
\hline & & Being full of Love & 3 \\
\hline & & Being Peaceful & 3 \\
\hline & & Being Excited & 3 \\
\hline & & Being able to express him/herself & 5 \\
\hline & & Being Creative & 1 \\
\hline & & Learning Emotions & 1 \\
\hline & & Expressing Emotions & 1 \\
\hline & & Being the Leader & 1 \\
\hline & & Being self-confident & 1 \\
\hline & & Decreasing Jealousy & 1 \\
\hline & & Total & 27 \\
\hline & & Final Total & 34 \\
\hline
\end{tabular}


When Table 12 was reviewed, the category referred to as "Emotional Development" has two sub-categories called "Positive Emotional Development" and "Negative Emotional Development". When the subcategory, "Negative Emotional Development" was reviewed, the codes belonging to this sub-category are Being rageful (3), Being stubborn (2), and Being sad (2), which have the frequency value of 7 in total. On the other hand, when the sub-category "Positive Emotional Development" was reviewed, the codes belonging to this sub-category are Being Happy (7), Being full of Love (3), Being Peaceful (3), Being Excited (3), Being able to express him/herself (5), Being Creative (1), Learning Emotions (1), Expressing Emotions (1), Being the Leader (1), Being self-confident (1), and Decreasing Jealousy (1). In total, it has a frequency value of 27 , and the frequency value in the final total is 34 .

Considering the participants' statements for the sub-category, "Negative Emotional Development";

Participant 1: "She gets nervous once she fails and becomes more ambitious than ever. She may feel rageful and throw her toy away. She gets sad when she is caught in Hide-and-Seek'.

Participant 2: “...he mostly learns how to be obstinate to one another outside, and the child he opposes could be somewhat different'”

On the other hand, as for the sub-category, "Positive Emotional Development";

Participant 1: "These games influence him in a positive way. He becomes more peaceful, that is, he doesn't get nervous, nor does he yell or cry'.

Participant 2: "It is in a positive way. She can express herself and speaks out what she wants, she can express her emotions".

Table 13. How do you think active games would affect your child's psycho-motor development?

\begin{tabular}{|c|c|c|c|}
\hline Category & Sub-Category & \multicolumn{2}{|l|}{ CODES } \\
\hline \multirow{12}{*}{ 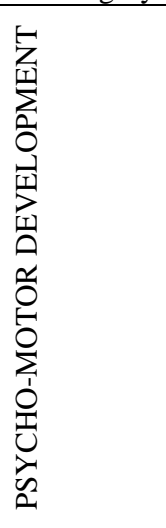 } & \multirow{10}{*}{ 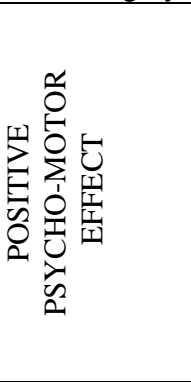 } & Positive Effect on Physical Development & 11 \\
\hline & & Handicraft /Manual Skill & 5 \\
\hline & & Verbal Skill & 4 \\
\hline & & Development of Movement & 4 \\
\hline & & Being Energetic & 3 \\
\hline & & Great Psycho-Motor Development & 2 \\
\hline & & Little Psycho-Motor Development & 1 \\
\hline & & No Problem in Weight Gain & 1 \\
\hline & & Feeling hungry & 1 \\
\hline & & Total & 32 \\
\hline & $\begin{array}{l}\text { NEGATIVE } \\
\text { PSYCHO- }\end{array}$ & Getting Tired & 1 \\
\hline & $\begin{array}{l}\text { MOTOR } \\
\text { EFFECT }\end{array}$ & Total & 1 \\
\hline & & Final Total & 33 \\
\hline
\end{tabular}


When Table 13 was reviewed, it was seen that the category referred to as "Psycho-motor Development" has two sub-categories called "Positive Psycho-motor Effect" and "Negative Psycho-motor Effect". It is seen that the codes of the sub-category called "Positive Psycho-motor Effect" are Positive Effect on Physical Development (11), Handicraft /Manual Skill (5), Verbal Skill (4), Development of Movement (4), Being Energetic (3), Great Psycho-Motor Development (2), Little Psycho-Motor Development (1), No Problem in Weight Gain (1), and Feeling hungry (1), which, in total, have the frequency value (32). In the sub-category called "Negative Psycho-motor Effect", however, only the code Getting Tired (1) was seen. In the final total, on the other hand,the frequency value is 33 .

Considering the participants' statements for the sub-category, "Positive Psycho-motor Effect";

Participant 1. "'There is definitely a very significant developmental effect that shows up. Her handicraft develops, and she is much healthier physically."'

Participant 2. "He doesn't become a bulky child, and he consumes his energy through movement, as a result of which he has no weight problem at all'”.

Participant 3. "He performs several movements correctly, and physically, a significant development emerges, and yes, it does have a positive effect'”.

As for the sub-category, 'Negative Psycho-motor Effect';

Only 1 Participant: "Since he has no concept of time developing in him, he doesn't even notice how much time he spends while playing a game, so he gets really tired'”.

Table 14. How do you think active games would affect your child's social development?

\begin{tabular}{|c|c|c|c|}
\hline Category & Sub-Category & Codes & $\mathrm{f}$ \\
\hline \multirow{11}{*}{ 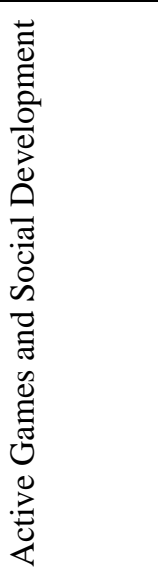 } & \multirow{3}{*}{ 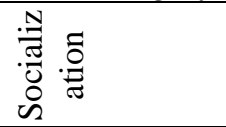 } & Being social & 9 \\
\hline & & Communication & 5 \\
\hline & & Total & 14 \\
\hline & \multirow{4}{*}{ 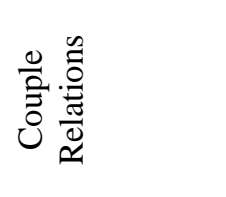 } & Learning how to share & 6 \\
\hline & & $\begin{array}{l}\text { Development in the Viewpoint towards } \\
\text { Relationships }\end{array}$ & 1 \\
\hline & & Establishing Friendship & 1 \\
\hline & & Total & 8 \\
\hline & \multirow{4}{*}{ 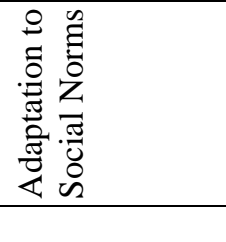 } & Adaptation to Social Norms & 3 \\
\hline & & Learning the Distribution of Tasks & 1 \\
\hline & & Total & 4 \\
\hline & & Final Total & 26 \\
\hline
\end{tabular}


When Table 14 was reviewed, it was seen that the category referred to as "Active Games and Social Development" has three sub-categories called "Socialization", "Couple Relations", and "Adaptation to Social Norms". It is seen that the codes of the sub-category called 'Socialization'" are Being social (9) and Communication (5). Thus, the frequency value in total is 14. In the second sub-category called "Couple Relations", the codes are Learning how to share (6), Development in the Viewpoint towards Relationships (1), and Establishing Friendship (1), which have the frequency value of 8 in total. In the third sub-category called "Adaptation to Social Norms”, the codes are Adaptation to Social Norms (3), Learning the Distribution of Tasks (1), which have the frequency value 4 in total. In the final total, the frequency value is seen to be 26 .

Considering the participants' statements;

Participant 1. "His adaptation and communication between him and his friends have progressed a great deal. I now observe that he has become more sociable’.

Participant 2. "She has learnt how to share her toys with others".

Participant 3. "He has learnt to follow the rules both in games and in social environments. In short, he is keeping away from his spoilsport attitude, and I believe games are absolutely the tools of socialization’.

\section{Discussion}

In this study, it was stated by parents that all of the children aged 4-5 had played “active games', 'Home', one of the 'Closed Areas' and which is also the sub-category of the category called 'Places of Active Games', was stated by parents to be the place where children often played games at most outside the school.

However, it was also stated by parents that their children often played active games together with them and that the periods of their game playing had lasted for 1-3 hours a day. In a conducted study, it is suggested that the games played and the activities performed in the open areas on weekdays and at the weekend had reinforced the relationship between parents and their children (Havigerova et al., 2015).

In a study conducted by Erbay and Saltali in 2012, it was found that children had spent most of their time outside the school by playing games and by watching TV. Also, they played their games together with their parents and friends at most. Thus, most of them played in their own rooms and in the living room when they were at home. In the study conducted by

Özyürek and Gürleyik (2016), which was carried out by using the semi-structured interview method along with 27 parents who had children aged 4-6, the parents stated the fact that although they had adequate knowledge as to the importance and benefits of games in their children's 
development, they failed to spare enough time to play with their children due to house chores and intensive business matters.

Separately, parents also said that they tried to spare some time to play with their children almost everyday. In a study conducted by Koçyiğit and Baydilek (2015) for the purpose of determining the perceptions of pre-school children over the concept of game, the children stated that their teachers had not participated in their games and that they usually played alone at home as well.

Furthermore, it was expressed by the parents that active games had generally posed a positive effect on the cognitive development of their children and that they also had a positive effect on the decision making and focusing processes. They mostly expressed the fact that active games had generally affected the emotional development of their children in a positive way, and they expressed this fact with the expressions: "Being Happy" and "Being able to Express Themselves", On the other hand, the parents who thought that active games had negative effects on the emotional development of their children stated this fact with the expression, "Being Rageful". Apart from this, parents are of the opinion that active games make great contributions to the psycho-motor development of their children, which was expressed by the statement, "Positive Effect on Physical Development". The conducted studies have shown that games had promoted children's development in several different fields. Durualp (2009) studied the effect of physical activities like games on the social skills of children. Accordingly, it was determined that social adaptation and skill levels pertaining to the children within the experimental group that took part in the game-based social skill training had proved to be higher than the children in the control group who did not take part in that training. Separately, the fact that active games had made positive contribution to the social development of children was stated by the parents by using the expressions, 'being sociable' 'establishing communication', and 'learning how to share'. For instance, children interact with others during the game. As a result, the development of children's social skills is supported. It is also accepted that games generate contexts/environments and opportunities in order to promote the cognitive, social, lingual, and communicative and motor developments of children, and that they support children's social emotional adaptations as well (Şahin, 2013).

When the results of the conducted study were reviewed, it was eventually seen that the viewpoints of parents about the effects of active games on the cognitive, social, emotional, and psycho-motor development areas of their children proved to be positive in general. 


\section{References:}

1. Aksoy, A. and Çiftçi, D.H. (2014). Erken Çocukluk Döneminde Oyun. 1. Bask1, Pegem Akademi: Ankara, 11-17.

2. Aral, N. , Gürsoy,F.,Köksal,A. (2001). Okul Öncesi Eğitimde Oyun. Yapa Yayın: İstanbul.

3. Auerbach, A. (2008). Çocuk Yetiştirmede oyunun Önemi. (Çev: Maide Meltem Açan), Yakamoz Yayınları: İstanbul, 1.baskı, 21-22.

4. Bacanlı, H. (2002). Gelişim ve Öğrenme. Nobel yayınları: Ankara, 6.Bask1, 77-79.

5. Başaran, M. (1992). Oyunlarla Spora Hazırlık. M.E. B. Yayınları: İstanbul.

6. Bernard, H. R. and Gravlee, C.C. (2015). Handbook of methods in cultural antropology. USA: Rowman and LittleField.

7. Durualp, E. (2009). Anasınıfına Devam Eden Altı Yaş Çocuklarının Sosyal Uyum ve Becerilerine Oyun Temelli Sosyal Beceri Eğitiminin Etkisinin İncelenmesi: Çankırı Örneği. Yayımlanmamış Yüksek Lisans Tezi. Ankara Üniversitesi, Fen Bilimleri Enstitüsü, Ankara.

8. Erbay, F., Durmuşoğlu Saltalı, N. (2012). Altı Yaş Çocuklarının Günlük Yaşantılarında Oyunun Yeri ve Annelerin Oyun Algısı. Ahi Evran Üniversitesi Kırşehir Eğitim Fakültesi Dergisi (KEFAD) 13 (2), 249-264

9. Erkuş, A. (2005). Bilimsel Araştırma Sarmalı. Ankara: Seçkin Yayıncilik.

10. Gül, K.G. (2011). Çocuklar ve Spor. Antrenör eğitim dizgisi: 1, Spor Yayınevi ve Kitabevi: Ankara, 12-13.

11. Havigerová, J. M., Šnoblová, M., and Truhlářová, Z. (2015). Common Activities of Parents and Preschool Children Strengthening Their Relationship. Procedia-Social and Behavioral Sciences, 186, 197-201.

12. Hazar, M. (2006). Beden Eğitimi ve Sporda Oyunla Eğitim. Ankara, 7-15.

13. Huizinga, J. (2013). Oyunun Toplumsal İşlevi Üzerine Bir Deneme. (Mehmet Ali Kılıçbay, Çeviren) Ayrıntı Yayınları: İstanbul.

14. Kandır, A. (2000). Okul öncesi dönemde oyun ve oyuncaklar. Gazi Üniversitesi Mesleki Eğitim Dergisi, (4), 77-80.

15. Koçyiğit, S., and Baydilek, N. B. (2015). Okul Öncesi Dönem Çocuklarinin Oyun Algilarinin İncelenmesi. Yüzüncü Y1l Üniversitesi Eğitim Fakültesi Dergisi, 12(1).

16. Miles, M. B. and Huberman, A.M. (1994). Qualitative data analysis :an expanded sourcebook. (2nd Edition). Calif.: SAGE Publications.

17. Mirzeoğlu, N. (2011). Spor Bilimlerine Giriş. Spor kuramı dizisi: 3, Spor Yayınevi ve Kitabevi: Ankara,110-113. 
18. Özdoğan, B (2000). Çocuk ve Oyun. Genişletilmiş Üçüncü Bask1. Ankara: Anı Yayıncilık .

19. Özyürek, A., and Gürleyik, S. (2016). Anne Babalarin Okul Öncesi Dönem Çocuklari İle Etkileşimlerinde Oyunun Yeri. Journal of International Social Research, 9(42).

20. Şahin R (2013). Okul Öncesi Dönem Görme Engelli Çocukların Oyun Çeşitlilik ve Karmaşıklık Düzeyini Artırmada Genişletme Tekniğinin Etkililiği, Ankara, Gazi Üniversitesi Eğitim Bilimleri Enstitisü, Özel Eğitim Bölümü, Görme Engellilerin Eğitimi Anabilim Dalı, Yüksek Lisans Tezi, 17.

21. Yıldırım, A., and Şimşek, H. (2013). Sosyal bilimlerde nitel araştırma yöntemleri. Ankara: Seçkin Yayıncılık. 